\title{
PROBLEMATIKA GURU DALAM MENERAPKAN PENDEKATAN SAINTIFIK DI MADRASAH IBTIDAIYAH NURUL QOMAR PALEMBANG
}

\author{
Ririn Zauharoh Tunaffisa
}

Prodi PGMI FITK UIN Raden Fatah Palembang ririnzauharohtunaffisa@gmail.com

\section{Muhamad Afandi}

Prodi PGMI FITK UIN Raden Fatah Palembang

muhammadafandi_uin@radenfatah.ac.id

\section{Kms. Mas'ud Ali}

Prodi PGMI FITK UIN Raden Fatah Palembang

kemasmasudali_uin@radenfatah.ac.id

\section{Abstrak}

Tujuan penelitian ini adalah untuk mengetahui pemahaman, langkah-langkah, dan problematika guru kelas V Madrasah Ibtidaiyah Nurul Qomar Palembang dalam menerapkan pendekatan saintifik. Metode penelitian ini menggunakan metode penelitian deskriptif kualitatif. Informan penelitian ini adalah guru kelas VMI Nurul Qomar Palembang. Teknik pengumpulan data menggunakan wawancara, observasi, dan dokumentasi. Teknik analisis datanya meliputi reduksi data, penyajian data, dan verifikasi data. Untuk uji keabsahan datanya dilakukan uji kredibilitas, dependabilitas, transfermabilitas, dan konfirmabilitas. Hasil penelitian ini antara lain: (1) Pemahaman guru kelas V di MI Nurul Qomar Palembang tentang pendekatan saintifiksudah baik; (2) Langkah-langkah guru kelas V di MI Nurul Qomar Palembang dalam menerapkan pendekatan saintifik belum semuanya diterapkan dengan maksimal; (3) Problematika guru kelas V Madrasah ibtidaiyah Nurul Qomar Palembang dalam menerapkan pendekatan saintifik adalah pada kegiatan menanya dan mengkomunikasikan.

Kata-kata kunci: guru, pendekatan, problematika, saintifik

\begin{abstract}
The purpose of this study was to determine the understanding, steps, and problems of the fifth grade teacher of Palembang Nurul Qomar Ibtidaiyah Madrasah in applying the scientific approach. This research method uses descriptive qualitative research methods. The informant of this study was the fifth grade teacher of MI Nurul Qomar Palembang. The technique of collecting data uses interviews, observation, and documentation. Data analysis techniques include data reduction, data presentation, and data verification. To test the validity of the data carried out a test of credibility, dependability, transferability, and confirmation. The results of this study include: (1) Understanding of fifth grade teachers in MI Nurul Qomar Palembang about the scientific approach is good; (2) The steps of the fifth grade teacher in MI Nurul Qomar Palembang in applying the scientific approach have not all been implemented maximally; (3)
\end{abstract}


Problems in class V teachers of Madrasah ibtidaiyah Nurul Qomar Palembang in applying the scientific approach is to ask questions and communicate.

Keywords: teachers, approaches, problems, scientific

\section{PENDAHULUAN}

Pada tahun 1974 atau sebelumnya mungkin terdapat kebanggaan tersendiri bagi pelaku pendidikan di Indonesia, jika berkumpul dengan pelaku pendidikan dari negara lain. Kebanggaan tersebut dikarenakan Indonesia dianggap sebagai negara yang berhasil melaksanakan pembangunan dibidang pendidikan, akan tetapi diawal abad ke-21 ini kebanggan tersebut perlahan-lahan sirna karena mutu pendidikan di Indonesia menunjukkan kecendrungan yang memprihatinkan (Wibawa, 2017: 1). Upaya yang dilakukan pemerintah dalam meningkatkan mutu pendidikan di Indonesia adalah melakukan perubahan dibidang pendidikan dengan pergantian kurikulum.

Kurikulum merupakan suatu program pendidikan yang direncanakan secara matang dan disusun secara sitematis untuk dijadikan acuan oleh pendidik dan peserta didik dalam proses pendidikan untuk mencapai tujuan yang telah ditetapkan (Dakir, 2010: 3). Melalui pergantian kurikulum diharapkan dapat membekali peserta didik dengan kompetensi yang dibutuhkan. Pergantian kurikulum yang dimaksud adalah pergantian kurikulum KTSP ke kurikulum 2013.

Perubahan merupakan sesuatu yang harus terjadi pada bidang pendidikan. Dalam rangka menerapkan pendidikan yang bermutu, pemerintah telah menetapkan Kurikulum 2013 untuk diterapkan pada sekolah/madrasah. Ada banyak komponen yang melekat pada Kurikulum Tahun 2013 ini. Hal yang paling menonjol adalah pendekatan dan strategi pembelajaran (Hosan, 2014: 31).

Hosnan (Muliatina, 2016) mengemukakan bahwa Kurikulum 2013 menganut pandangan dasar bahwa pengetahuan tidak dapat dipindahkan begitu saja dari guru-peserta didik. Peserta didik adalah subjek yang memiliki kemampuan untuk secara aktif mencari, mengelola, mengkonstruksi, dan menggunakan pengetahuan. Pada hakikatnya, sebuah proses pembelajaran yang dilakukan di kelas-kelas bisa kita pandang sebagai sebuah proses ilmiah. Oleh 
sebab itu, di dalam Kurikulum 2013 dijelaskan secara rinci tentang pendekatan saintifik dalam proses pembelajaran (Nurdin dan Andrianto, 2016: 302).

Implementasi pendekatan saitifik dalam pembelajaran di kurikulum 2013 adalah proses pembelajaran yang dilaksanakan agar peserta didik lebih aktif secara mandiri dalam membangun konsep, hukum atau prinsip dengan tahapan: mengamati, membuat hipotesis, mengumpulkan data, menganalisis data, menarik kesimpulan, dan mengkomunikasikan (Hosan, 2014: 34). Tujuan pendekatan saintifik dalam pembelajaran adalah untuk meningkatkan kecerdasan, khususnya kemampuan berfikir tingkat tinggi siswa, mengembangkan karakter siswa dan diperolehnya hasil belajar yang tinggi (Daryanto, 2014: 54).

Berdasarkan observasi yang dilakukan di MI Nurul Qomar Palembang hari Senin, tanggal 10 September 2018. Diketahui bahwa sebagian guru di MI Nurul Qomar Palembang tersebut kurang menguasai cara mengajar dengan menggunakan Kurikulum 2013. Terutama pada pendekatan saintifik.Ibu Nurul Hidayah S. Pd selaku guru kelas V di MI Nurul Qomar mengatakan di dalam wawancaranya yaitu pendekatan saintifik memiliki langkah-langkah pembelajaran yang meliputi tindakan mengamati, menanya, mengumpulkan informasi, mengasosiasi, dan mengkomunikasikan (5M).Namun masih banyak guru yang mengalami kesulitan dalam menggunakan pendekatan saintifik untuk mengajar dalam kelas.Kesulitanyang dihadapi oleh guru dalam menggunakan pendekatan ini dapat timbul karena kurangnya persiapan yang dilakukan dan kurangnya pemahaman guru tentang esensi pendekatan saintifik.

\section{METODE PENELITIAN}

Metode penelitian ini menggunakan metode penelitian kualitatif dengan pendekatakan deskriptif. Informan penelitian ini adalah guru kelas VMI Nurul Qomar Palembang. Teknik pengumpulan data menggunakan wawancara, observasi, dan dokumentasi. Teknik analisis datanya meliputi reduksi data, penyajian data, dan verifikasi data atau penarikan kesimpulan. Untuk uji keabsahan datanya dilakukan uji kredibilitas, dependabilitas, transfermabilitas, dan konfirmabilitas. 


\section{HASIL PENELITIAN}

\section{Pemahaman Guru Kelas V di MI Nurul Qomar Palembang Tentang Pendekatan Saintifik}

Lembaga pendidikan tentunya akan lebih berkembang jika dapat mengikuti perkembangan zaman, untuk itu pemerintah telah melakukan pembaharuan dengan pergantian kurikulum, yaitu kurikulum 2013 yang ahirnya mampu melahirkan pendekatan-pendekatan baru salah satunya adalah pendekatan saintifik, bahkan langkah dari pendekatan saintifik ini melekata pada RPP kurikulum 2013 pada kegiatan inti yaitu kegitan mengamati, menanya, mengumpulkan informasi, mengasosasi dan mengkomunikasiikan.

Berdasarkan hasil wawancara yang peneliti lakukan hari senin 25 Februari 2019 dengan ibu Nurul Hidayah selaku wali kelas V MI Nurul Qomar Palembang, tentang pendekatan saintifik, beliau mengatakan di dalam wawancaranya bahwa:

"Pendekatan saintifik adalah pendekatan yang lahir dari Kurikulum 2013 yang merupakan pendekatan ilmiah dan memiliki langkah-langkah mengamati, menanya, mengumpulkan informasi, mengasosiasi, mengkomunikasikan"

Berdasarkan RPP yang ibu Nurul Hidayah buat, di dalam kegiatan inti memang tertuliskan adanya kegiatan mengamati, menanya, mengumpulkan informasi, mengasosiasi, dan mengkomunikasikan secara terpisah-pisah dan jelas.

Berdasarkan hasil pengamatan yang dilakukan peneliti selama satu minggu, ibu Nurul sudah menerapkan pembelajaran dengan menggunakan pendekatan saintifik sesuai dengan RPP yang beliau buat.

Pendekatan saintifik adalah pendekatan terbaru dalam dunia pendidikan, yang tentunya memiliki tujuan, dengan berbagai keunggulan dan fungsi, ibu Nurul di dalam wawancaranya mengatakan bahwa:

"Tujuan pendekatan saintifik untuk meningkatkan kecerdasan dan kemampuan berfikir tingkat tinggi siswa, karena Kurikulum 2013 lebih menekankan siswanya untuk aktif.Dapat dikatakan bahwa siswa harus lebih mandiriKeunggulan pendekatan saintifik jelas untuk menuntut siswa berfikir kritis dan aktif, namun kelemahannya untuk siswa yang cara berfikirnya lambat akan ketinggalan materi pembelajaran. Pendekatan saintifik adalah pendekatan yang berpusat pada siswa, jadi fungsinya untuk meningkatkan kecerdasan siswa" 
Berdasarkan hasil observasi yang peneliti lakukan studi dokumentasi dari RPP ibu Nurul sudah sangat baik, ibu Nurul juga sudah menguasai cara mengajar menggunakan pendekatan saintifik, sehingga tujuan pembelajarannya terlihat dapat tercapai dengan sangat memuaskan.

\section{Langkah-langkah yang Diterapkan Guru di MI Nurul Qomar Palembang dalam Pembelajaran dengan Menggunakan Pendekatan Saintifik}

\section{Mengamati}

Salah satu langkah pendekatan saintifik adalah kegiatan mengamati, biasanya kegiatan mengamti ini ada pada kegiatan inti bagian awal, karena sebagai pembuka pembelajaran, kegiatan mengamati juga dapat dilakukan dengan berbagai cara, bukan hanya mengamati papan tulis, namun dapat juga mengamati buku, atau objek yang berhubungan dengan pembelajaran.

Berdasarkan hasil penelitian yang peneliti peroleh melalui metode wawancara. Ibu Nurul Hidayah di dalam wawancaranya mengatakan:

"Selalu menggunkan kegiatan mengamati saat proses pembelajaran, baik mengamati gambar, buku, maupun keadaan lingkungan sekitar, namun beliau mengatakan tidak pernah belajar di luar kelas, jadi pengamatan yang dilakukan selalu terjadi di dalam kelas. Dan tidak mengalami kendala pada kegiatan mengamati"

Berdasarkan studi dokumentasi dari RPP yang ibu Nurul buat, kegiatan mengamati yang ada di dalam RPP adalah (siswa mengamati bagian-bagian informasi penting dari bacaan dan merumuskan komponen-komponen yang penting dalam sebuah ekosistem).

Berdasarkan hasil pengamatan peneliti selama 1 minggu, kegiatan mengamti yang sering ibu Nurul lakukan adalah observasi berstruktur. Pada observasi berstruktur dalam rangka proses pembelajaran, fenomena subjek, objek atau situasi apa yang ingin diobservasi oleh peserta didik telah direncanakan secara sistematis di bawah bimbingan guru, kegiatan ini sudah baik dilakukan oleh ibu Nurul.

Berdasarkan hasil penelitian yang diperoleh peneliti menggunakan metode observasi, wawancara dan dokumentasi.Pada kegiatan mengamati ini, ibu Nurul

JIP: Jurnal Ilmiah PGMI, Volume 5 No. 1, Juni 2019

Available Online at http:/jurnal.radenfatah.ac.id/index.php/jip/ 
sudah sangat baik melaksanakannya, kegiatan mengamati yang ibu Nurul lakukan juga sudah sesuai dengan RPP guru.

\section{Menanya}

Kegiatan menanya sebenarnya sudah ada sebelum adanya pendekatan saintifik, namun di dalam langkah-langkah pendekatan saintifik menyantumkan adanya kegiatan menanya setelah kegiatan mengamati, kegiatan menanya ini biasanya terjadi antara siswa dengan siswa, siswa dengan guru.

Berdasarkan hasil penelitian yang diperoleh peneliti melalui metode wawancara.ibu Nurul di dalam wawancaranya mengatakan:

"Kegiatan menanya memang sudah semestinya ada dalam proses pembelajaran, kegiatan menanya ini juga selalu diterapkan saat pembelajaran, baik itu pertanyaan yang bersifat individu maupun kelompok, baik pertanyaan tertulis maupun lisan, namun saya kurang bisa memunculkan rasa ingin tahu siswa untuk bertanya, karena setiap saya kasih waktu untuk bertanya secara lisan saat proses pembelajara siswa hanya diam, saat saya memberikan pertanyaan juga sangat jarang siswa yang mau menjawab pertanyaan."

Berdasarkan studi dokumentasi dari RPP yang ibu Nurul buat, kegiatan menanya yang ada di dalam RPP adalah (siswa mencermati daftar pertanyaan tentang ekosistem dan secara bergantian menjawab pertanyaan guru).

Hasil pengamatan yang dilakukan peneliti menujukkan bahwa, ibu Nurul sering menggunakan kegiatan menanya tingkatan pertanyaan kognitif yang lebih rendah, sub-tingkat pengetahuan, karena pertanyaan yang ibu Nurul sering gunakan adalah apa, siapa, kapan, dimana, sebutkan, jodohkan atau pasangkan, persamaan kata, golongkan, dan berilah nama, kegiatan ini sudah baik dilakukan oleh ibu Nurul. Namun ibu Nurul kurang bisa memancing emosional dan rasa keingin tahuan siswa untuk bertanya pada proses pembelajaran. Siswa masih sangat jarang mau bertanya dan menjawab pertanyaan guru secara lisan. Sesekali ibu Nurul menunjuk siswa agar mau bertanya dan menjawab pertanyaan yang guru berikan, tujuannya agar siswa terbiasa berbicara di depan teman-temannya.

Peneliti melihat pada kegiatan menanya, melalui metode wawancara, observasi dan dokumentasi. Kegiatan menanya masih belum terlaksana dengan baik, meski ibu Nurul mengatakan di dalam wawancaranya tidak ada kendala di 24

JP: Jurnal Ilmiah PGMI, Volume 5 No. 1, Juni 2019 Available Online at http:/jurnal.radenfatah.ac.id/index.php/jip/ 
dalam kegiatan menanya, namun saat proses pembelajaran terlihat ibu Nurul kesulitan memancing keingintahuan siswa, karena siswa sangat jarang mau tunjuk tangan dan bertanya maupun menanya secara lisan saat proses pembelajaran.

\section{Mengumpulkan Informasi/Data}

Kegiatan mengumpulkan informasi biasanya dilakukan setelah kegiatan mengamati dan menanya.Dan kegiatan mengumpulkan informasi biasanya dilakukan bukan hanya di dalam kelas, dan bukan hanya mencari informasi dari dalam buku, namun bisa juga dari Koran, TV, atau internet dll.

Berdasarkan hasil penelitian yang dilakukan dengan metode wawancara.ibu Nurul di dalam wawancaranya mengatakan

"Kegiatan mengumpulkan informasi sudah sering ia terapkan dalam pembelajaran, kegiatan mengumpulakan informasi yang biasa diterapkan adalah dengan menyuruh siswa membaca buku, karena dari buku mereka bisa mendapatkan informasi, dan tidak mengalami hambatan dalam menerapkannya."

Berdasarkan studi dokumentasi dari RPP yang ibu Nurul buat.Kegiatan mengumpulkan informasi yang ada di dalam RPP adalah (siswa berlatih untuk mengidentifikasi karakteristik benda hidp dan benda mati dari buku pegangan siswa).

Berdasarkan hasil pengamatan yang dilakukan peneliti menggunakan metode observasi, pada kegiatan mengumpulkan informasi atau data ibu Nurul sering menggunkan jenis mengumpulakan informasi membaca buku, kegiatan ini sudah baik di lakukan oleh ibu Nurul.

Berdasarkan hasil penelitian, yang dilakukan peneliti menggunakan metode wawancara, dokumentasi dan dokumentasi, kegiatan mengumpulkan data sudah baik diterapkan oleh ibu Nurul, kegiatan mengumpulkan data yang ibu Nurul terapkan juga sudah sesuai dengan RPP, tidak ada kendala yang ibu Nurul hadapi pada kegiatan mengumpulkan data.

\section{Mengasosiasi}

Hasil penelitian yang diperleh peneliti mengunakan metode wawancara, ibu Nurul di dalam wawancaranya mengatakan 
"Saya selalu mengggunakan kegiatan menalar saat pembelajaran, karena dengan menalar siswa akan berfikir leebih kritis, dan menemukan pemikiran-pemikiran yang lebih mendalam, namanya anak SD kegiatan menalarnya harus dilakukan deengan cara memberikan pertanyaanpeertanyaan, dengan diberikan pertanyaan atau soal, siswa akan mulai menalar dan berfikir untuk mnemukan jawaban dari pertanyaan yang saya berikan, tidak ada kendala dalam kegiatan menalar."

Berdasarkan studi dokumentasi dari RPP yang ibu Nurul buat, kegiatan mengasosiiasi yang ada di dalam RPP adalah (siswa mengidentiifikasi gambar lingkaran dan unsure-unsr penting dalam sebuah lingkaran diantaranya jari-jari, diametr, luas dan keliling lingkaran).

Berdasarkan hasil pengamatan yang diperoleh peneliti menggunakan meode observasi, kegiatan mengasosiasi yang sering dilakukan ibu Nurul adalah menalar secara induktif, kegiatan ini sudah baik diterapkan oleh ibu Nurul.

Berdasarkan hasil penelitian yang diperoleh peneliti dengan menggunakan metode pengumpulan data wawancara, observasi dan dokumentasi.Kegiatan mengasosiasi memang sudah terlaksana dengan baik sesuai dengan wawancara, observasi, dan RPP guru, tidak ada kendala yang ibu Nurul hadapi pada kegiatan mengasosiasi.

\section{Mengkomunikasikan}

Kegiatan mengkomunikasikan biasanya selalu terletak di akhir pembelajaran, kegiatan mengkomunikasikan bisa di lakukan satu arah, dua arah atau bahkan bisa juga dilakukan banyak arah.

Berdasarkan hasil penelitian yang diperoleh peneliiti menggunakan metode wawancara. Ibu Nurul di dalam wawancaranya mengatakan:

"Kegiatan mengkomunikasikan sudah diterapkan setiap proses pembelajaran, baik komunikasi sesama siswa maupun antara siswa dan guru, tidak ada kendala pada kegiatan mengkomunikasikan."

Berdasarkan RPP yang ibu Nurul buat, kegiatan mengkomunikasikan yang ada di dalam RPP adalah (siswa bersama-sama mengkomunikasikan menghitung keliling lingkaran secara bersama-sama).

Berdasarkan hasil penelitian yang diperoleh peneliti menggunakan metode observasi.kegiatan mengkomunikasikan yang sering ibu Nurul gunakan adalah 26

JP: Jurnal Ilmiah PGMI, Volume 5 No. 1, Juni 2019

Available Online at http:/jurnal.radenfatah.ac.id/index.php/jip/ 
jenis mengkomunikasikan satu arah yaitu guru sebagai pemberi aksi dan siswa sebagai penerima aksi. Kendala ibu Nurul dalam kegiatan mengkomunikasikan ini terlihat jelas, karena beliau kurang bisa memancing emosional siswa dan rasa ingin tahu siswa, terbukti saat ibu Nurul melakukan kegiatan mengkomunikasikan jenis yang digunakan adalah komunikasi satu arah, jadi guru yang aktif siswa pasif.Pada kegiatan mengkomunikasikan langsung digabuungkan dengan kegiatan penutup yaitu menarik kesimpulan, padahal RPP yang ibu Nurul buat, kegiatan mengkomunikasikan terpisah dari kegiatan menarik kesimpulan.

Jadi berdasarkan hasil penelitian yang diproleh peneliti mengunakan merode observasi dan wawancara.Kegiatan mengkomunkasikan yang ibu Nurul terapkan terlalu monoton, tidak melibatkan keaktifan siswa, karena pada kegitan mengkomunikasikan ibu Nurul hanya menggunakan komunikasi satu arah, ibu Nurul juga langsung menggabungkan kegiatan mengkomunikasikan dengan kegiatan penutup (menarik kesimpulan), padahal di RPP kegiata tersebut terpisah. Dan ibu Nurul juga tidak mengatakan ada kendala pada kegiatan mengkomunikasikan.

\section{Problematika yang Dihadapi Guru Kelas V di MI Nurul Qomar Palembang dalam Menerapkan Pembelajaran dengan Menggunakan Pendekatan Saintifik}

Pendekatan saintifik adalah pendekatan yang muncul setelah adanya kurikulum baru, yaitu kurikulum 2013, jadi tidak heran jika masih ada sebagian guru yang mengalami kesulitan dan kendala saat menerapkan pendekatan saintifik, ibu Nurul di dalam wawancaranya mengatakan bahwa:

"Tidak mengalami kendala pada kegiatan pembelajaran dengan menggunakan pendekatan saintifik, dari kelima langkah kegiatan yang ada pada pendekatan saintifik saya hanya mengalami kendala pada kegiatan menanya, karena siswa selalu terlihat pasif saat saya menyuruh mereka bertanya secara lisan saat proses pembelajaran"

Berdasarkan hasil penelitian yang peneliti lakukan menggunakan metode observasi menunjukkan bahwa memang kendala yang ibu Nurul hadapi saat menerapkan pendekatan saintifik adalah pada kegiatan menanya, terlihat saat penerapan kegiatan menanya ibu Nurul belum bisa memancing emosional dan rasa ingin tahu siswa untuk bertanya dan menjawab pertanyaan guru secara lisan

JP: Jurnal Ilmiah PGMI, Volume 5 No. 1, Juni 2019 
saat pross pembelajarn berlangsung. Namun peneliti melihat bukan hanya kegiatan menanya kendala yang ibu Nurul hadapi, pada kegiatan mengkomunikasikan ibu Nurul sering menggunakan jenis komunikasi satu arah yaitu guru sebagai pemberi aksi dan siswa sebagai penerima aksi, hal ini menyebabkan guru aktif dan siswa pasif.

\section{PEMBAHASAN}

\section{Pemahaman Guru Kelas V di MI Nurul Qomar Palembang Tentang} Pendekatan Saintifik

Pergantian Kurikulum 2013 telah melahirkan banyak sekali strategi dan berbagai pendekatan, salah satunya adalah pendekatan saintifik yaitu pendekatan yang memiliki lima langkah dalam pembelajaran diantaranya adalah kegiatan mengamati, menanya, mengumpulkan informasi, dan mengasosiasi. Kelima langkah tersebut juga terlihat lebih terperinci lagi saat dicantumkan di dalam RPP, kegatannya juga lebih terstruktur dan terarah.

Sedangkan Pendekatan saintifik menurut ibu Nurul di dalam wawancaranya adalah pendekatan yang lahir dari Kurikulum 2013 yang merupakan pendekatan ilmiah dan memiliki langkah-langkah mengamati, menanya, mengumpulkan informasi, mengasosiasi dan mengkomunikasikan. Hal ini sesuai dengan definisi pendekatan saintifik menurut Hosan, (2014: 34). Implementasi Kurikulum 2013 dalam pemblajaran dengan pendekatan saintifik adalah proses pembelajaran yang dirancang sedemikian rupa agar pserta didik secara aktif mengkonstruk konsep, hukum, atau prinsip melalui tahapan-tahapan mengamti, menanya, mengumpulkann data dengan berbagai teknik, menganalisis data dan mengkomunikasikan konsep, hukum, atau perinsip yang ditemukan.

Berdasarkan hasil penelitian dapat disimpulkan bahwa pemahaman guru kelas V di MI Nurul Qomar Palembang tentang pendekatan saintifiksudah baik, juga sudah menguasai cara mengajar menggunakan pendekatan saintifik, sehingga tujuan pembelajarannya terlihat dapat tercapai dengan sangat memuaskan. 


\section{Langkah-langkah yang Diterapkan Guru di MI Nurul Qomar Palembang dalam Pembelajaran dengan Mengunakan Pendekatan Saintifik}

Langkah-langah pendekatan saintifik sebenarnya sudah ada sebelum adanya pendekatan saintifik, namun di dalam pendekatan saintifik langkah-langkah tersebut di susun dengan lebih terarah dan sistematis, langkah pendekatan saintifik adalah mengamati,menanya, mengumpuulkan informasi, mengasosiasi dan mengkomunikasikan.

Dari hasil observasi dan wawancara, langkah-langkah pendekatan saintiifik belum semuanya diterapkan dengan baik, masih ada dua kegiatan yang masih mengalami kendala dalam penerapannya, yaitu kegiatan menanya dan mengkomunikasikan.

\section{Mengamati}

Berdasarkan hasil wawancara, observasi dan dokumentasi ibu Nurul tidak mengalami kesulitan pada kegiatan ini.

\section{Menanya}

Pada kegiatan menanya, guru terlihat kesulitan mengajak siswa untuk melakukan Tanya jawab secara lisan saat proses pembelajaran, terlihat jelas guru yang selalu memberikan pertanyaan, dan sedikit siswa yang mau menjawab pertanyaan guru, guru masih belum bisa menimbulkan rasa ingin tahu siswa. Hal ini tidak sesuai dengan kompetensi yang diharapkan dalam kegiatan menanya menurut Daryanto (2014: 63), kompetensi yang diharapkan dalam kegiatan ini adalah mengembangkan kreativitas, rasa ingin tahu, kemampuan merumuskan pertanyaan untuk membentuk pikiran kritis untuk hidup cerdas dan belajar sepanjang hayat.

\section{Mengumpulkan Informasi}

Berdasarkan hasil wawancara, dokumentasi dan obsrvasi, ibu Nurul Hidayah tidak mengalami kesulitan atau kendala dalam kegiatan mengumpulkan informasi. 


\section{Mengasosiasikan}

Berdasarkan hasil wawancara, dokumentasi dan obsrvasi, ibu Nurul hidayah tidak mengalami kesulitan atau kendala dalam kegiatan mengumpulkan informasi.

\section{Mengkomunikasikan}

Pada kegiatan mengkomunikasikan, guru hanya menggunakan komunikasi satu arah, sehingga siswa terlihat pasif, guru tidak memberikan kesempatan kepada siswa untuk mengkomunikasikan apa yang telah mereka pelajari, guru perlu memberikan jenis komunikasi yang bervariasi dengan menggunakan jenis komunikasi yang berbeda sesuai dengan kebutuhan. Ibu Nurul juga melakuakan kegiatan mengkomunikasikan dengan kegiatan menarik kesimpulan secara bersamaan, namun di dalam RPP kegiatan mengkomunikasikan dan kegiatan menarik kesimulan dituliskan berbeda.Hal tersebut tidak sesuai dengan yang di kemukakan Daryanto (2014: 80), pada pendekatan saintifik diharapkan guru memberi kesempatan kepada peserta didik untuk mengkomunikasikan apa yang telah mereka pelajari, kegiatan ini dapat dilakukan melalui menuliskan atau menceritakan apa yang ditemukan dalam mencari informasi, jenis kegiatan mengkomunikasikan ada tiga jenis yaitu, komunikasi satu arah, komunikasi dua arah, dan komunikasi banyak arah.

\section{Problematika yang Dihadapi Guru Kelas V di MI Nurul Qomar Palembang} dalam Menerapkan Pembelajaran dengan Menggunakan Pendekatan Saintifik

Dari hasil observasi dan wawancara, problematika dalam menerapkan pendekatan saintifik yang ibu Nurul hadapi ada dua, yaitu pada kegiatan menanya dan mengkomunikasikan.Berdasarkan wawancara ibu Nurul hanya mengalami kesulitan pada kegiatan menanya, namun pada hasil observasi peneliti, ibu Nurul mengalami kesulitan dalam menerapkan kegiatan menanya dan mengkomunikasikan.

Ibu Nurul mengalami kesulitan saat menerapkan kegiatan menanya, terlihat jelas saat proses pembelajaran, ibu Nurul kurang bisa memotivasi siswa untuk mau bertanya langsung saat proses pembelajaran, dan hal ini suai dengan pendapat Darnius (2016: 40-48) di dalam penelitiannya bahwa pada kegiatan 
menanya, guru merasa kesulitan untuk memotivasi siswa untuk mau bertanya tentang permasalahan yang belum peserta didik mengerti dan guru juga kewalahan dalam menumbuhkan motivasi siswa untuk mau mengluarkan pendapat agar pmbelajaran dapat berlangsung dengan aktif.

\section{SIMPULAN}

Pemahaman guru kelas V di MI Nurul Qomar Palembang tentang pendekatan saintifiksudah baik, juga sudah menguasai cara mengajar menggunakan pendekatan saintifik, sehingga tujuan pembelajarannya terlihat dapat tercapai dengan sangat memuaskan.

Langkah-langkah guru kelas V di MI Nurul Qomar Palembang dalam menerapkan pendekatan saintifik belum semuanya diterapkan dengan maksimal, masih ada dua kegiatan yang masih mengalami kendala dalam penerapannya, yaitu kegiatan menanya dan mengkomunikasikan.

Problematika guru kelas V Madrasah ibtidaiyah Nurul Qomar Palembang dalam menerapkan pendekatan saintifik adalah pada kegiatan menanya dan mengkomunikasikan.Pada kegiatan menanya adalah guru kurang bisa memancing rasa ingin tahu siswa untuk bertanya saat proses pembelajaran. Sedangkan problematika pada kegiatan mengkomunikasikan adalah terlalu seringnya menggunakan kegiatan komunikasi satu arah, yaitu guru sebagai pemberi aksi dan siswa sebagai penerima aksi sehingga guru aktif dan siswa pasif.

\section{DAFTAR PUSTAKA}

Basuki Wibawa. (2017). Manajemen Pendidikan Teknologi Kejujuran dan Vokasi. Jakarta. Bumi Aksara.

Dakir. (2010). Perencanaan dan Pengembangan Kurikulum. Jakarta. Rineka Cipta.

Daryanto.(2014). Pendekatan Pembelajaran Saintifik Kurikulum 2013. Yogyakarta. Gava Media.

Dwi Adi. (2001). Kamus Besar Bahasa Indonesia.Surabaya. Fajar Mulya Surabaya.

Kemendikbud.(2013). Pendekatan dan Strategi Pembelajaran.Jakarta. Kemdikbud. 
M. Hosan. (2014). Pendekatan Saintifik dan Kontekstual dalam Pembelajaran Abad 21. Jakarta. Ghalia Indonesia.

Meaty H. Idris.dkk. (2015). Menjadi Pendidik yang Menyenangkan \& Profesional Implementasi pada Pendidikan Anak Usia Dini. Jakarta Timur.PT Luxima Metro Media.

Muliatina. (2016). Kendala Guru dalam Menerapkan Pendekatan Saintifik Kurikulum 2013 Di SDN Teupin Pukat Meureudu Pidie Jaya. Jurnal Ilmiah Mahasiswa Priodi PGSD FKIP Unsyiah.Volume 1. Nomor 1. Agustus

Nana Sudjana.(1998). Cara Belajar Siswa Aktif dalam Proses Belajar Mengajar.Bandung. Sinar Baru Algesindo.

Nazarudin Rahman. (2014).Menjadi Guru Profesional.Yogyakarta. Pustaka Felicha.

Said Darnius. (2016). Identifikasi Kesulitan Guru dalam Mengimplementasikan Kurikulum 2013 dengan Pendekatan Saintifik di Kelas Tinggi Gugus Mangga Kecamatan Jaya Baru Banda Aceh. Jurnal Pesona Dasar. Volume 2. Nomor 4. April.

Syafrudin Nurdin. (2016). Adrianto. Kurikulum dan Pembelajaran. Jakarta. PT Grafindo Persada.

Widido.(2002). Kamus Besar Bahasa Indonesia.Jakarta. Absolut. 